\title{
Alabio ducks, germplasms of South Kalimantan, as protein and income sources
}

\author{
Eni Siti Rohaeni ${ }^{1}$, Ratna Ayu Saptati $^{2}$, and Lintje Hutahaean ${ }^{1}$ \\ ${ }^{1}$ Indonesian Center for Agricultural Technology Assessment and Development, Bogor 16114, \\ Indonesia \\ ${ }^{2}$ Indonesian Center for Animal Research and Development, Bogor 16151, Indonesia
}

\begin{abstract}
Apart from providing food originating from meat and eggs, Alabio ducks have another important role for farmers in South Kalimantan, namely as an income source, employment source, and preservation of local genetic source. This paper aimed to study the economic profile of Alabio ducks in several types of businesses in Hulu Sungai Utara Regency, South Kalimantan. A survey method was carried out on several groups of duck farmers. In order to obtain more in-depth information, a focus group discussion (FGD) was held with key insiders in the duck industry. The results showed that the duck farming business has good prospects and can be a source of income and employment for farmers and young generations. The business of hatchery, slaughter-duck producers, hatching egg producers, and consumes-egg producers, is economically feasible. Improving biosecurity and handling and managing environmental sanitation have to carry out, among others, through pens, equipment, and environmental disinfection, as well as routine vaccinations with the escort and support of local and central government. In addition, to increase the welfare and income of farmers need to introduce technological innovations that can increase farming efficiency.
\end{abstract}

\section{Introduction}

Changes in consumption patterns certainly follow the increase in people's welfare, one of which is by increasing the need for animal protein. Poultry is a source of animal protein and is mainly raised by the community. In addition to being easy to maintain, the cost of poultry farming is also cheaper than other livestock. A common type of poultry that plays an important role in meeting the nutritional needs of the community is ducks. Alabio duck is one of the local livestock commodities developed as a germplasm resource in South Kalimantan. Alabio ducks have an important role for farmers in South Kalimantan, namely

\footnotetext{
Corresponding author: ratnaayusaptati@yahoo.com
} 
as a source of animal food from meat and eggs, a source of farmers' income, creating employment opportunities, and at the same time as a genetic source of local germplasm.

The Alabio duck development center area in the province of South Kalimantan is in Hulu Sungai Utara Regency. The population of ducks in this area reached 1,492,013 heads or about $34.98 \%$ of the total duck population (4,264,995 heads) in 2018. A high population of ducks in HSU Regency shows that ducks have an important role for farmers in HSU. The production of duck eggs and meat in HSU Regency in 2018 was 10,230,946 kg and 525,634 kg, respectively. This production contributes to the production of eggs and duck meat in South Kalimantan Province reached $34.98 \%$ and $39.72 \%$ respectively [1].

As an effort to protect local genetic resources, the results of the Arabio duck color pattern research (Anas platyrhynchos Borneo) in South Kalimantan showed that the dominant color pattern of Alabio male ducks from Hulu Sungai Utara (HSU) was grayish-brown fur on the neck (56\%), grayish-brown on the chest $(72 \%)$, black-gray on the hindquarters $(60 \%)$, bluishgreen on the wings $(56 \%)$, and black on the tail $(80 \%)$. The female Alabio duck from HSU has a grayish-brown color pattern around the neck, back, chest, and tail ranging from 46.29 to $82.85 \%$, and grayish-black on the wings by $40.57 \%$. The differences in the dominant color of feathers that occur in male and female ducks is due to the different selection systems carried out by farmers. Usually, farmers make selections based on the uniformity of coat color phenotype, without considering the pedigree [2].

HSU Regency's duck farming industry specializes in a number of businesses, namely consumer egg producers, hatching egg producers, DOD producers (hatcheries), slaughter duck producers (finishing), and breeding to produce pre-laying female duck [3]. This article aims to determine the business profile of Alabio Duck in several types of businesses, the germplasm as a source of protein, and the revenue source in Hulu Sungai Utara Regency in South Kalimantan.

\section{Materials and methods}

\subsection{Tannery process of tilapia fish skin}

The research was conducted in North Hulu Sungai Regency, South Kalimantan Province, from June to October 2018. The research method used was a survey of several groups of duck farmers who run businesses, namely slaughter-duck producers (fattening), breedings, hatching-egg producers, consumes-egg producers, hatchery, and duck traders. Focus group discussion with key informants was also conducted to obtain more in-depth information.

The data used include primary data and secondary data. Primary data were obtained through interviews with farmers and field observations. Secondary data in the form of related data published by BPS, Dinas, Pusdatin as well as theories and results of previous research obtained through library research. The number of respondents as many as 53 respondents.

In addition to descriptive analysis to explain other parameters and their relationships, net farm income analysis and $\mathrm{R} / \mathrm{C}$ ratios are also used to analyse the commercial viability of each business understudy. According to [4], income is the difference between income and all costs. Meanwhile, farmers' income is the multiplication between the production obtained and the selling price. Analysis of the contribution of duck farming income to the Provincial Minimum Wage (UMP) was obtained by comparing the income to the UMP using one year period and multiplied by $100 \%$. The UMP value used is the 2018 South Kalimantan UMP, which is IDR 2,454,671 (BPS, 2019). The formula used as follows:

$$
\mathrm{T} 1=\mathrm{TR}-\mathrm{TC}
$$

where:

TI $=$ Total income of duck business 
$\mathrm{UMPj}=$ the provincial minimum wage

\section{Results and discussion}

\subsection{Characteristics of duck farmers}

The average age of farmers was 43.03 years, and was included in the productive age, so that it was assumed to have high motivation and business spirit. A person's age affects the ability to carry out an activity, including farming [5]. At productive age, a person's ability if healthy, is in optimal condition to have work motivation, abilities and hone skills. The average education of respondents was 7.44 years. Although the level of education was relatively low, the ability of reading and writing can be used as capital to supports running their business. Education level has something to do with information acceptance and technology adoption. A person's education will determine the views, mindset, and decision making on a problem [5]. Furthermore, [5] reported that education level and age had a positive but not significant effect on farmers' income. The results of another study reported by [6] that age has an effect on income while education has no effect. Household labor is the number of production workers owned by agricultural households that can participate in crop/plantation and livestock production activities, expressed in working days (HOK). $1 \mathrm{HOK}$ is equivalent to 8 working hours per day, 25 days per month, and 300 days per year. Based on the data above, the average availability of family labor was $849 \mathrm{HOK} /$ year, but only $690 \mathrm{HOK}$ used to work in agriculture (Table 1).

Table 1. Characteristics of duck farmers in Hulu Sungai Utara

\begin{tabular}{|l|c|}
\hline \multicolumn{1}{|c|}{ Description } & Average \\
\hline Age of the head of the family (year) & 43,03 \\
\hline Education of the head of the family (year) & 7,44 \\
\hline Number of household member (people) & 4,64 \\
\hline Age $<15$ years old & 1,81 \\
\hline Age $>15$ years old & 2,83 \\
\hline Number of family labor works in agriculture (people) & 2,3 \\
\hline Experience in duck farming (year) & 15,2 \\
\hline
\end{tabular}

Table 2. Asset control by duck farmers in Hulu Sungai Utara, 2018

\begin{tabular}{|c|c|}
\hline \multicolumn{1}{|c|}{ Description } & Average \\
\hline Land (ha) & \\
\hline a. Paddy field & 0.73 \\
\hline b. Tidal land & 0.30 \\
\hline c. Others: garden, not utilized & 0.65 \\
\hline Total & 1.68 \\
\hline Poultry asset (head) & 241 \\
\hline a. Duck & 28 \\
\hline b. Chicken & 70 \\
\hline Business scale of duck farming based on business type: & 83 \\
\hline a. Breedings (head) & 130 \\
\hline b. Slaughter-duck producer (head) & 96 \\
\hline c. Hatching-eggs producer (head) & $500-3,000$ \\
\hline d. Consumes-eggs producer (head) & \\
\hline e. Hatchery (egg/week) & \\
\hline
\end{tabular}


The existing duck business specialties in Hulu Sungai Utara are breeding, producing slaughter-duck (fattening), producing hatching-eggs, consumes-eggs, and hatchery. In breedings, farmers are raising ducks to produce duck seeds. Farmers sell ducks based on consumer demand in the form of ducklings with an age of 1 month to 5 months. The longer the selling time, the higher the production cost. The production system in breedings is usually uses extensive and semi-intensive systems.

Production of slaughter-ducks (fattening male ducks) have mostly used an intensive and semi-intensive system. Producers of hatching eggs, using the ratio of raising male and female ducks for 1:10-20. This production system ranged from extensive, semi-intensive, and intensive systems. The average scale of this business was around 130 heads per farmer, which was higher than the scale of consumes-egg producers. The higher scale of hatching egg production was due to the higher price of hatching eggs about IDR 200-300 / egg compared to the price of consumes-eggs. Hatching-egg price was also relatively stable at IDR 2,400$2,500 /$ egg compared to consumes-eggs, which continue to fluctuate in the same one-year period due to season. The range of consumes-eggs price was between IDR 1,900/egg to IDR 2,500/egg. The production of consumes-eggs was mostly done with an intensive system. Duck hatchery was carried out per week, with a scale between 500-1,500 eggs/week and ducklings sell at the ages of 1-7 days.

[7] pointed out that for low-income countries with food shortages, poultry farming is still considered an important source of protein, and provide additional income for smallholder farmers (especially women) with limited resources. Although it requires low capital, poultry farming contributes significantly to food security, poverty alleviation, and environmentally friendly management of natural resources. Poultry farming is a source of employment for underprivileged groups in many local communities. However, the constraints faced by the poultry production system are poor management conditions and an underdeveloped marketing structure. The skills and abilities of smallholders in all aspects of the poultry business have to improve through training and education. Credit or loans have to give to smallholder farmers, taking into account the economic circumstances and socio-cultural context in which the beneficiaries live. More than that, to reach business sustainability, the marketing system must be improved. Barriers faced by small-scale poultry farming in the future, with a particular focus on poultry disease given the current outbreak of highly pathogenic avian influenza in Asia. Identification of geographic hot spots needs to be done so that it can be determined where the most urgent intervention is needed, and where the location of small-scale farming has the potential to generate large impacts [8].

\subsection{DOD-producing hatchery}

The average age of farmers in hatcheries was 40.75 years with an average of 12 years of education (high school graduation). This age is in the productive age category, and the education level is quite good. Farmers with a good level of education usually have a good level of understanding in receiving information and innovation. The average experience in hatching and trading ducks was 20 years, and the average number of hatching eggs was about 2014 eggs/week. Hatching uses a combination of a hatching machine and hatchery bales. The average number of hatching machines was 4.25 units/family with a capacity of between 5001,000 eggs. The average price for hatching machines was IDR 2,800,000/unit. DOD was mainly sold in HSU Regency (60\%), and the rest is outside HSU Regency and South Kalimantan, each accounting for $20 \%$ (Table 3).

Farmers sell DOD all at once, and if there are any leftovers, farmers will raise and sell them in the following week. The demand for DOD usually increases after the rice harvest season ends. This situation especially occurs in the HSU area, which is a lowland area during the dry season and may be suitable for semi-intensive duck farming. The type of duck will 
affect the price of the duck. There is no difference between the price of one-day-old male and female Peking ducks between 6000-7000 IDR/head. As for Alabio ducks, there was a price difference between male and female DOD. The price of female DOD is more expensive than that of male DOD. Female DOD are IDR 10,000-12,000/head, and male DOD are only IDR 2,000-3,000/head.

Table 3. Characteristics of hatchery farmer in HSU, 2018

\begin{tabular}{|l|c|}
\hline \multicolumn{1}{|c|}{ Description } & Average \\
\hline Age (year old) & 40.75 \\
\hline Education (year) & 12 \\
\hline Number of household member (people) & \\
\hline Age $<15$ years old & 2 \\
\hline Age $>15$ years old & 3 \\
\hline Experience in hatching and trading ducks (year) & 20 \\
\hline Number of duck egg hatched (egg/week) & 2014 \\
\hline Number of hatching machine (unit) & 4.25 \\
\hline Percentage of DOD sold (\%): & \\
\hline a. in HSU & 60 \\
\hline b. Outside HSU & 20 \\
\hline c. Outside province & 20 \\
\hline Percentage of not hatched egg (\%) from: & \\
\hline a. Infertile egg & 90.31 \\
\hline b. Fertile egg & \\
\hline
\end{tabular}

The hatchery business scale ranged from 800-5,000 eggs/week/farmer with an average of 2,014 eggs/week. Hatchability was about $61.24 \%$. The incubator system used is a mixture of an incubator and husk. Egg germination was $90.31 \%$. Farmers did candle eggs 4 (four) times, about $8.68 \%$ of total eggs hatched did not grow, and about $7.77 \%$ of the number of eggs that entered the incubator were eggs with dead embryos in them. Farmers sold infertile eggs at a price of between IDR 1,900- IDR 2,000/egg, while dead embryo eggs were between IDR 1,000- IDR 1,600/egg. Respondent utilized dead embryo eggs for feed mixtures. Sometimes, it was difficult for farmers to obtain uniform hatching eggs. Farmers did not encounter any problems related to the ducklings sold. Generally, hatchery farmers already have regular suppliers of hatching eggs and guarantee their availability. However, when the demand for DOD increases, especially in March - September, it is sometimes difficult for farmers to obtain hatching eggs. DOD marketing is not difficult, because it already has a fixed market and customers. Farmers regulate the number of eggs hatched according to fluctuations in DOD demand. The problems that farmers often face are frequent power 
outages that affect the hatching rate, the availability of a sufficient number of hatching eggs, and limited funds.

\subsection{Duck and egg trader}

Duck products sold are in the form of edible/consumes-eggs, hatching eggs, DOD, slaughter ducks, pre-laying female ducks, and rejected ducks (duck that no longer produce). The duck product market is located in the North Hulu Sungai (HSU) Regency and is open every Wednesday. The average age of a duck trader was 51 years with a bachelor's education, both of which indicate that the quality of human resources for duck traders was quite good, so that they were actively involved in communication or information about duck development. Traders had 27.5 years of experience in duck trading. The average sales of ducklings were 3,000 heads/week, young ducks were 150 heads/week, and adult ducks were 100 heads/week.

Traders sold ducks to meet demand in South Kalimantan, Central Kalimantan, and East Kalimantan. For several years, with the exception of Central Kalimantan and East Kalimantan, almost no ducks have been delivered or sold outside the provinces. In addition to HSU itself, there are also HST, HSS, Banjar, Tapin, Tanah Laut, and Banjarmasin, who have purchased a large number of ducks in South Kalimantan.

Table 4. Characteristics of duck trader in Hulu Sungai Utara, 2018

\begin{tabular}{|l|c|}
\multicolumn{1}{|c|}{ Description } & Average \\
\hline Age (year old) & 51 \\
\hline Education (year) & 16 \\
\hline Number of household member (people) & 3 \\
\hline Age $<15$ years old & 2 \\
\hline Age $>15$ years old & 2 \\
\hline Experience in duck trading (year)) & 27.5 \\
\hline Scale of sale (head): & 3,000 \\
\hline Duckling (DOD) & 150 \\
\hline Young duck & 100 \\
\hline Adult duck & \\
\hline
\end{tabular}

Demand for ducks has increased from March to April and August to September. This is because the transition season has passed, so the disease outbreak will not affect duck raising. In addition, August and September are the dry seasons, the harvest of rice has been completed, and duck raising can be extensively carried out in the paddy field. Due to the outbreak of many diseases, the demand for ducks is reduced during the transition seasons and the peak of the rainy season.

The price of ducks increased in line with the increase in demand. Depending on the age and quality of the ducks, the price of ducklings will increase by IDR 3,000-4,000 per head, while the prices of young and adult ducks will increase by IDR 10,000-30,000 per head. The sale of eggs or live ducks is relatively unproblematic because their demand determines their 
prices. This fact is consistent with the views of [9] and [10] that duck products, whether eggs, DOD, slaughtered ducks, or laying ducks, are relatively easy to sell.

There were several routes in the marketing system of ducks, namely:

1. Hatchery - Trader - Farmer (ducklings)

2. Hatchery - Trader - External Trader - Farmer (ducklings)

3. Farmer - Trader - Farmer (young duck/adult duck)

4. Farmer - Trader - Consumer (young duck/adult duck)

The sales scale of duck eggs per week was 1,500 eggs/trader according to market prices. An average of 15 years of duck egg trading experience. The eggs sold are for consumption, so the average buyer likes Peking duck eggs because of their large size.

\subsection{Duck hatchery}

Table 5. Economic analysis of duck hatchery in Mamar Village, HSU Regency

\begin{tabular}{|c|c|c|c|c|c|}
\hline \multicolumn{1}{|c|}{ Description } & \multicolumn{2}{|c|}{ Number } & $\begin{array}{c}\text { Price/unit } \\
\text { (IDR) }\end{array}$ & Total (IDR) & \% \\
\hline Expenditure (IDR): & & & & & \\
\hline Hatching egg & 1,000 & eggs & 2,500 & $2,500,000$ & 76.34 \\
\hline Feed & 1 & zak & 375,000 & 375,000 & 11.45 \\
\hline Medicine & 1 & unit & 100,000 & 300,000 & 9.16 \\
\hline Electricity & 1 & month & 50,000 & 50,000 & 1.53 \\
\hline Sexing wage & 1 & time & 50,000 & 50,000 & 1.53 \\
\hline Total & & & & $3,275,000$ & \\
\hline Revenue (IDR): & & & & & \\
\hline Selling of: & & & & & \\
\hline Female DOD & 300 & heads & 12,000 & $3,600,000$ & \\
\hline Male DOD & 300 & heads & 3,000 & 900,000 & \\
\hline Candling egg 1 & 50 & eggs & 1,700 & 85,000 & \\
\hline Candling egg 2 & 50 & eggs & 1,700 & 85,000 & \\
\hline Candling egg 3 & 50 & eggs & 1,000 & 50,000 & \\
\hline Total & & & & & \\
\hline Income (IDR) & & & & & \\
\hline R/C & & & & & \\
\hline
\end{tabular}

Source: Author's survey, 2018 
The results of the analysis on duck hatchery business on a scale of 1,000 eggs a week and in an $\mathrm{R} / \mathrm{C}$ value of 1.42 , which means that the hatchery was profitable and feasible to do. The prices and assumptions that apply were in accordance with the data in Table 5. Farmers did this business throughout the year, but in certain months will increase the scale of their business because demand increases. The increase in demand for ducklings occurs during the dry season. This condition is because farmers have a lot of time after harvesting the food crops, and the land is available. What's more, in the dry season, the air becomes hot and not humid, so the ducks become healthier. The research result of Purnomo [11] that hatching duck eggs using an incubator with a capacity of 200 eggs was profitable and feasible with an $\mathrm{R} / \mathrm{C}$ value of 1.3 . In order to obtain more profit and serve as the main income, the number of incubators needs to be increased to at least six units. The structure of the incubator needs to be further studied to increase the hatching rate.

The hatchery business of 1,000 duck eggs/week has created an average income of IDR $4,635,000 /$ week. The largest expenditure of the hatchery business is $76.34 \%$ of the purchase of hatching eggs, and only $11.45 \%$ of the feed, because the ducklings produced between 1-7 days are sold immediately.

\subsubsection{Duck breeding}

The business of breeding ducks to mature female ducks (pre-laying duck) was feasible, with an $\mathrm{R} / \mathrm{C}$ value of 1.65 and a business scale of 175 . Feed cost was the largest cost incurred, accounting for $64 \%$, and the cost of purchasing ducklings accounts for $30.34 \%$. The weakness of duck breeding is that it takes a long time so that there turn of business capital takes time (Table 6).

Table 6. Economic Analysis of duck breeding to pre-laying duck, 2018

\begin{tabular}{|c|c|c|c|c|c|}
\hline \multicolumn{1}{|c|}{ Description } & \multicolumn{2}{|c|}{ Number } & $\begin{array}{c}\text { Price/unit } \\
\text { (IDR) }\end{array}$ & Total (IDR) & \% \\
\hline Expenditure (IDR): & & & & & \\
\hline Duckling & 175 & heads & 15,000 & $2,625,000$ & 30.34 \\
\hline Commercial feed & 4 & zak & 380,000 & $1,520,000$ & 17.62 \\
\hline Rice bran & 250 & kg & 2,800 & 700,000 & 8.12 \\
\hline Sago & 11 & sticks & 300,000 & $3,300,000$ & 38.26 \\
\hline Others & 1 & package & 480,000 & 48,000 & 5.57 \\
\hline Total & & & & $8,625,000$ & \\
\hline Revenue (IDR): & 150 & heads & 95,000 & $14,250,000$ & \\
\hline $\begin{array}{l}\text { Selling of pre- } \\
\text { laying duck }\end{array}$ & & & & & \\
\hline & & & & $5,625,000$ & \\
\hline Income (IDR) & & & & 1.65 & \\
\hline R/C & & & & & \\
\hline
\end{tabular}




\subsection{Egg producer (hatching-egg and consumes-egg)}

The duck raising business that produces hatching eggs (Table 7) and consumes-eggs (Table 8 ) generated an $\mathrm{R} / \mathrm{C}$ value higher than 1 , which means that both businesses were feasible and profitable. In the consumes-eggs production, the biggest cost was the cost of feed, which reached $74.95 \%$, while the cost of purchasing duck breeds was only $22.23 \%$. The results of the analysis in the consumes-eggs production with a scale of 212 heads obtained an $\mathrm{R} / \mathrm{C}$ value of 1.24. The monthly income generated was IDR 1,721,234 (Table 7).

The analysis of hatching egg producer was carried out on a business scale of 183 heads, with some value assumptions described in Table 8 . The cost for feed was $78.70 \%$ and the cost of brood stock was $17.92 \%$. The analysis results showed that the business was profitable and feasible (R/C 1.27) and the income was IDR 1,859,666/month.

In the business of raising ducks, it is feasible to produce both hatching eggs and consuming eggs. Pay attention that there are no fatal diseases and insect pests. This fact is not much different from the study reported by Sitorus et al. [12]. The traditional laying duck business is feasible, with an $\mathrm{R} / \mathrm{C}$ value of 1.58 .

Due to the intensive raising of ducks, farmers must provide sufficient feed, and the cost of feed used by farmers for production consumes-eggs and hatching-eggs is more than $70 \%$. Gutterres et al.[13] also said the same thing, that the cost of feed is the largest component in duck farming, which reaches $70 \%$ of the total cost. For the production of ducks, the feed costs incurred are lower, which is only $64 \%$, because there is a mixture of maintenance, namely when ducks aged from a day to 1 month are intensively raised and after that, the ducks are raised in a semi-intensive way so that there is a saving in feed costs. The results of research by Soekarwati [14], stated that there was no difference in the size and quality of Alabio Duck eggs with intensive and semi-intensive maintenance, this fact was the basis so that it was sufficient to carry out semi-intensive maintenance. 
Table 7. Economic analysis of consumes-egg producer with a scale of 212 heads, 2018

\begin{tabular}{|c|c|c|c|c|c|}
\hline Description & \multicolumn{2}{|c|}{ Number } & \multirow{2}{*}{$\begin{array}{l}\text { Price/unit } \\
\text { (IDR) }\end{array}$} & \multirow[t]{2}{*}{ Total (IDR) } & \multirow[t]{2}{*}{$\%$} \\
\hline Expenditure (IDR): & & & & & \\
\hline Fixed Cost (IDR): & & & & & \\
\hline Duck brodstock & 212 & heads & 90,000 & $19,080,000$ & 22.23 \\
\hline Equipment & 1 & year & 250,000 & 250,000 & 0.29 \\
\hline Electricity & 1 & year & 600,000 & 600,000 & 0.70 \\
\hline Cage depreciation & 1 & year & $1,000,000$ & $1,000,000$ & 1.17 \\
\hline Variable Cost (IDR): & & & & & \\
\hline Feed & 1 & year & $64,320,000$ & $64,320,000$ & 74.95 \\
\hline Medicine & 1 & year & 222,000 & 222,000 & 0.26 \\
\hline Others & 1 & year & 350,000 & 350,000 & 0.41 \\
\hline Total Costs (IDR) & & & & $85,822,000$ & \\
\hline Revenue (IDR): & & & & & \\
\hline Consumes-egg & 46,428 & eggs & 2,079 & $96,523,812$ & \\
\hline Rejected duck & 175 & heads & 50,000 & $8,750,000$ & \\
\hline Manure & 1 & year & $1,203,000$ & $1,203,000$ & \\
\hline Total Revenue (IDR) & & & & $106,476,812$ & \\
\hline Income (IDR) & & & & $20,654,812$ & \\
\hline Montly income (IDR) & & & & $1,721,234$ & \\
\hline $\mathrm{R} / \mathrm{C}$ & & & & 1.24 & \\
\hline
\end{tabular}


Table 8. Economic Analysis of harching-egg producer with a scale of 183 heads, 2018

\begin{tabular}{|c|c|c|c|c|c|}
\hline \multirow{2}{*}{$\begin{array}{c}\text { Description } \\
\text { Expenditure (IDR): }\end{array}$} & \multicolumn{2}{|c|}{ Number } & \multirow{2}{*}{$\begin{array}{c}\text { Price/unit } \\
\text { (IDR) }\end{array}$} & \multirow[t]{2}{*}{ Total (IDR) } & \multirow[t]{2}{*}{$\%$} \\
\hline & & & & & \\
\hline Fixed Cost (IDR) & & & & & \\
\hline Duck brodstock & 183 & head & 80,000 & $14,640,000$ & 17.92 \\
\hline Equipment & 1 & year & 200,000 & 200,000 & 0.24 \\
\hline Electricity & 1 & year & 600,000 & 600,000 & 0.73 \\
\hline Cage depreciation & 1 & year & $1,000,000$ & $1,000,000$ & 1.22 \\
\hline Variable Cost (IDR): & & & & & \\
\hline Feed & 1 & year & $64,284,000$ & $64,284,000$ & 78.70 \\
\hline Medicine & 1 & year & 600,000 & 600,000 & 0.73 \\
\hline Others & 1 & year & 360,000 & 360,000 & 0.44 \\
\hline Total Costs (IDR) & & & & $81,684,000$ & \\
\hline Revenue (IDR): & & & & & \\
\hline Hatching egg & 40,000 & & 2,400 & $96,000,000$ & \\
\hline Rejected duck & 160 & & 50,000 & $8,000,000$ & \\
\hline Total & & & & $104,000,000$ & \\
\hline Pendapatan & & & & $22,316,000$ & \\
\hline Pendapatan per bulan & & & & $1,859,666$ & \\
\hline $\mathrm{R} / \mathrm{C}$ & & & & 1.27 & \\
\hline
\end{tabular}

\subsection{Duck farming income to the Provincial Minimum Wage (PMW)}

The duck hatchery business with a scale of 1,000 eggs/week can generate revenue of IDR 2,454,671 per month higher than the provincial minimum wage (UMP) applicable in South Kalimantan in 2018. This result is not much different from the research reported by Purnomo [11] that the duck hatchery business can meet the South Kalimantan UMP of (IDR 1,870,000) and can be a source of income with a scale of 1,200 points.

The production of hatching-egg can generate $75.76 \%$ of UMP's revenue. The breeding business to produce duck brood stock which carried out for 4 months provided the smallest 
income compared to the types of duck farming (Table 9). Duck hatchery business is feasible to be carried out as the main business because the income generates disgreater than the applicable UMP. For other types of duck business, it still needs diversification with other commodity farming or non-agricultural businesses. The reality found in the field is that most farmers carryout several types of commodities to be cultivated other than livestock, especially rice and vegetables. Research conducted in Tegal and reported by [15] that farmers who apply technology well can generate income above the minimum wage (IDR 975,000).

Table 9. Income of duck farming to the UMP of Kalimantan Selatan, 2018

\begin{tabular}{|c|l|c|c|}
\hline No & \multicolumn{1}{|c|}{ Business } & Montly income (IDR) & $\%$ \\
\hline 1 & Hatchery & $5,440,000$ & 221.62 \\
\hline 2 & Breeding & $1,406,250$ & 57.29 \\
\hline 3 & Consumes-egg producer & $1,721,234$ & 70.12 \\
\hline 4 & Hatching-egg producer & $1,859,667$ & 75.76 \\
\hline
\end{tabular}

Source: Author's survey,2018

\subsection{Internal and external factors in duck farming}

The strength is the long-term experience in raising livestock, with an average of more than 10 years, and strong motivation for breeding. Even if the livestock is affected by the disease, the farmer will not easily get discouraged and stand up again. What's more, HSU regency is a duck development center supported by institutions. The weakness is that the limited capital and technological mastery are still considered low. The external factor that influences is the opportunity in the form of a market for livestock products every Wednesday, and the opening of markets outside the district and province. Government support is an important factor, in addition to a supportive environment such as available land and local feed ingredients. Another important support is infrastructure in the form of roads and markets. Threats that are often faced in raising ducks are disease attacks that can cause their business to go out of business, the change of seasons that cause livestock to get sick.

Table 10. Identification of factors in the development of duck farming in Hulu Sungai Utara Regency, 2018

\begin{tabular}{|c|c|}
\hline \multicolumn{1}{|c|}{ Internal } & \multicolumn{1}{c|}{ External } \\
\hline Strength: & Opportunity: \\
Experience & Market \\
Motivation & Government support \\
Capital & Supportive environment \\
Central area & Adequate infrastructure \\
Solid group & \\
\hline Weakness: & Threat: \\
Funds/capital & Disease \\
Technology applied & Weather/Season transition \\
& Import \\
& Decreasing quality of duck broodstok \\
\hline
\end{tabular}

Since the avian influenza virus attack in 2010, it has caused some changes, including the entry and development of other duck species besides Alabio, such as Peking duck, Mojosari 
duck, MA duck, Tegal duck, and so on. This outbreak has led to a decline in the scale of farmers raising ducks, which in turn affected the decline in the Alabio duck population. Before the outbreak of duck disease, the scale of duck farming was generally more than 200 heads per household, and some even reached the scale of thousands of ducks. The important factor identified is the forecast related to the price fluctuations of duck eggs, which are expected to be high in the month of Ramadan (Ramadan) from the middle to the end of the month and in the month of Maulud (Islamic celebration). Low egg prices are predicted to occur at the time of the entry of eggs from Java, the fish season, the beginning of the month of Ramadan. Due to the sufficient local feed supply and the ease of raising ducks, the highest record for ducks occurred during the dry season, from July to September. The disease usually occurs in April and May (transition season).

Some of the problems identified from the FGD results include:

1. Disease

2. Seed quality

3. Feed price

4. Product selling price fluctuates (eggs and livestock)

Based on the problems faced, the recommended policies include:

- Vaccination of ducks routinely according to age

- Maintain the cleanliness of the cage and the environment by disinfection regularly,

- Conducting selection in the seedling area,

- $\quad$ Optimizing the use of local feed along with training for farmers to be able to produce a good quality of feed,

- Low-cost processing of animal products training,

- Livestock product processing promotion

- Government facilitation for the development of a mini-feed mill

\section{Conclusion}

Duck farming has good prospects as a source of income and employment for farmers and the younger generation. The results of the business analysis how that they are all feasible in terms of hatching, production, and slaughter of ducks, production of hatching eggs, or consumption of eggs. The duck hatchery is a reliable business and it can generate more revenue than the applicable UMP. Developing of duck business needs escorts from related agencies, especially in disease prevention and control as well as assistance in technological innovation. Another important thing is the need for handling and managing environmental sanitation to keep it clean and healthy, efforts to spray cages and cleanse the cage environment, as well as vaccinations, are important. 


\section{References}

1. A. J. Farid, P. H. Riyadi, U. Amalia, Indones. J. Fish. Sci. Technol. 10, 80-83 (2015)

2. S. Moroki, A.J. Masinambow, B. Kalangi. J. Berkala Ilm. Eff. 8, 132-142 (2018)

3. R. Olivi, R. Qurniati Firdasari. J. Sylva. Les. 3, 1-12 (2015)

4. F. F. Gueye, World. Poult. Sci. J. 58, 54-57 (2002)

5. V. Sivakumar, R. P. Prakash, P. G. Rao, B. V. Ramabrahmam, G. Swaminathan, J. Clean. Prod. 16, 549-553 (2008)

6. S. Mack, D. Hoffmann, J. Otte, World. Poult. Sci. J. 51, 7-14 (2005)

7. M. S. Rajasa, D. Sumardjono, B.T Eddy, Anim Agri J. 1, 331-341 (2012)

8. O. Sjofjan, D.N. Adli, M.H. Natsir, Y.F. Nuningtyas, T.S. Wardani, I. Sholichatunnisa, S.N. Ulpah, Firmansyah, O. JITV. 26, 39-48 (2021)

9. A. Wakhid, Buku Pintar Beternal Itik dan Bisnis Itik, (Agro Media, Jakarta, Indonesia, 2010)

10. N. Haq, Yunizal, Suherman, Teknologi Pengawetan dan Penyamakan Kulit Ikan (Pusat Penelitian dan Pengembangan Eksplorasi Laut dan Perikanan, Jakarta, Indonesia, 2000)

11. E. Purnomo, Penyamakan Kulit Reptil (Kanisius, Yogyakarta, Indonesia, 2001)

12. P. A. Sitorus, P. H. Riyadi, E. Susanto, Jurnal Ilmu dan Teknologi Perikanan 2, 57-64 (2020)

13. M. Gutterres, L. M. D. Santos, J. Soc. Leather Technol. Chem. 93, 171-175 (2009)

14. Soekarwati, Prinsip Dasar Ekonomi Pertanian - Teori dan Aplikasi, (PT.Raja Grafindo, Jakarta, Indonesia, 2002).

15. S. N. Hastang, Sirajudin, Asnawi, S. Kadir, Mahyudin. IOP Conf. Series : Earth and Environmental Sci. 492 (2020) 